\title{
The Job Market for Political Scientists in 1998: The Good News and The Bad
}

\author{
Sue Davis, American Political Science Association
}

Ph.

.D. political science departments reported an overall placement rate of $71 \%$ for 1998 . That is good news, inasmuch as it indicates that 1998 job candidates found work at about the same rate as their predecessors. In addition, the percentage of jobs available in Ph.D. programs has held fairly steady at $40 \%$ over the last 10 years. The bad news, or at least a portion of it, is that just under $30 \%$ of those with advanced degrees in political science do not find employment in a typical year, and nearly a third $(31 \%)$ of those who do find work accept temporary positions. As a consequence, the job search is made more difficult for new entrants to the political science marketplace as a substantial proportion of the un-, irregularly, and underemployed job candidates from previous classes continue or resume their job searches; in 1998, $43 \%$ of job seekers were "repeat customers." Also confounding the success of political science job candidates in 1998 was an unexpectedly low demand for new faculty in M.A. departments, and the continued de- cline in demand by undergraduateonly departments.

The data presented in this article come from APSA's annual placement survey of Ph.D.-granting departments of political science. During the fall of each year, APSA sends out surveys to all doctoral departments, asking for information on the placement class of the previous year. In 1999, 87 departments $(70 \%)$ provided information on their 1998 placement candidates. Despite repeated followups, 44 departments did not return surveys, making this report somewhat less than fully representative of the experiences of all 1998 political science job seekers.

Table 1 shows the basic demographic profile of the 1998 placement class. There were 955 job seekers, of whom 820 were U.S. citizens. The majority were men (68\%), and individuals with Ph.D.s in hand constituted three-fifths of the placement class. Even though ABDs find jobs at a much lower rate than Ph.D.s, many still go on the market each year. American government and public law scholars made up $30 \%$ of the class, with comparativists (27\%) making up the next largest cohort.

Over the last 10 years, the number of job candidates has risen substantially (with some variation in the trend), but the overall placement rate has remained fairly constant. Any fluctuations in the latter ratio can likely be accounted for by the varying response rate of Ph.D. departments. The proportion of candidates on the job market for at least a second year decreased slightly from 1997, but is much higher than in 1988 .

Table 3 shows several important trends. First, nonacademic placements have almost doubled, rising from $8 \%$ to $15 \%$, over the last 10 years. Second, the number of hires by M.A. and undergraduate departments has fallen sharply since 1988 . Finally, postdoctoral placement, which we only began tracking in 1997 , held steady at $6 \%$. It is important to note that postdoctoral scholars hold temporary positions of widely varying prestige and compensation.

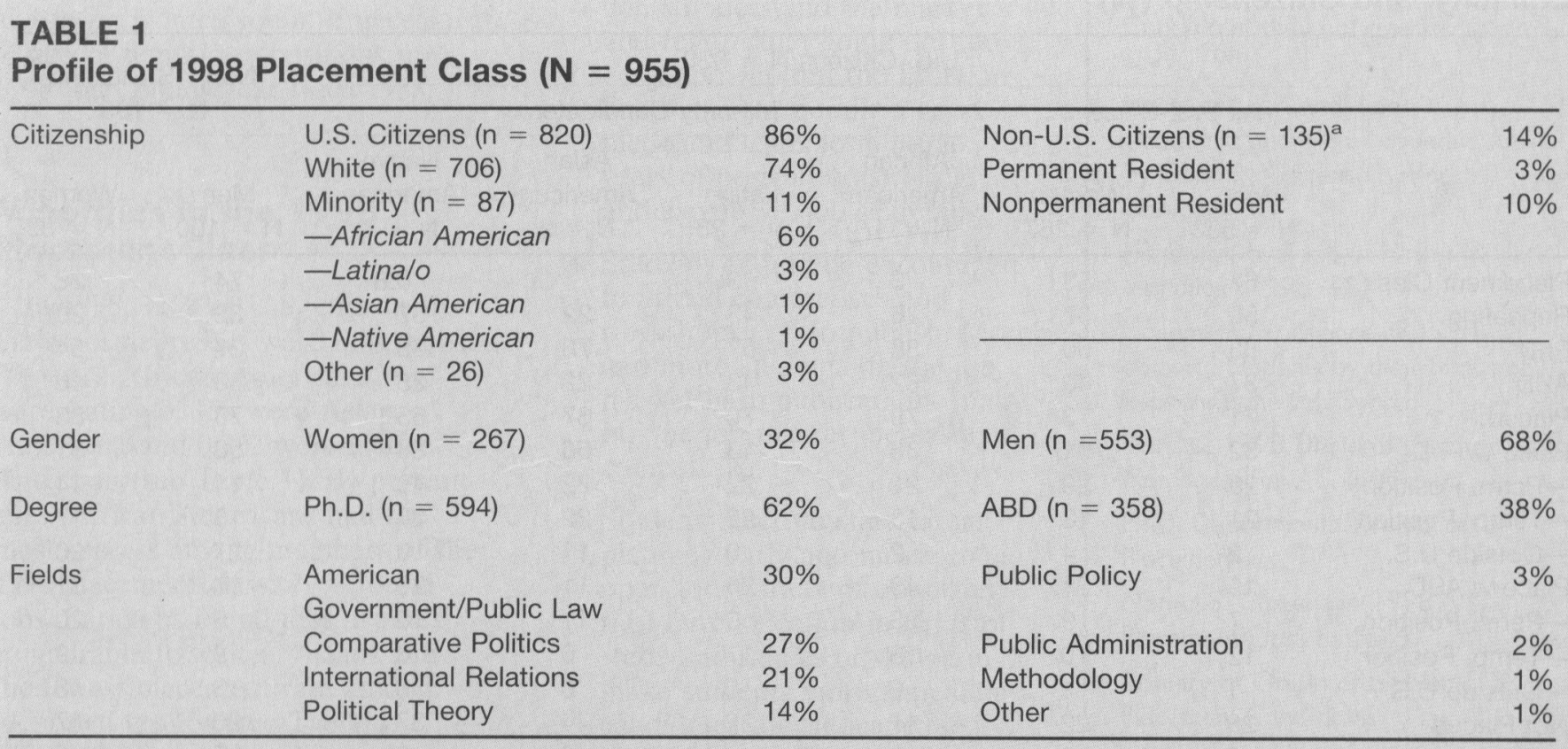

aPercentages do not add up to $100 \%$ due to rounding. 


\section{TABLE 2}

\section{Trends in Placement}

\begin{tabular}{|c|c|c|c|c|c|c|c|c|}
\hline & 1998 & 1997 & 1996 & 1995 & 1994 & 1992 & 1990 & 1988 \\
\hline Number of Job Candidates & 955 & 1112 & 984 & 799 & 1037 & 763 & 823 & 740 \\
\hline$\%$ of Overall Placement Success & 71 & 70 & 65 & 72 & 69 & 74 & 72 & 69 \\
\hline$\%$ of Candidates Repeating Job Search & 43 & 46 & 46 & 41 & 40 & 33 & 32 & 32 \\
\hline$\%$ of Ph.D.'s in Placement Class & 62 & 58 & 57 & 56 & 59 & 59 & 59 & 64 \\
\hline$\%$ of Women in Placement Class & 32 & 28 & 29 & 28 & 27 & 30 & 26 & 25 \\
\hline
\end{tabular}

Note: Response rates to APSA placement survey of U.S. Ph.D.-granting political science departments vary by year. 1998: 87 departments (70\% response rate); 1997: 105 (81\%); 1996: 97 (76\%); 1995: 95 (73\%); 1994: 106 (81\%); $1992: 110$ (87\%); 1990: 118 (93\%); 1988: $115(92 \%)$.

\section{TABLE 3}

\section{Placement by Type of Hiring Institutions, 1990-98 (\%)}

\begin{tabular}{|c|c|c|c|c|c|c|c|c|}
\hline & 1998 & 1997 & 1996 & 1995 & 1994 & 1992 & 1990 & 1988 \\
\hline Ph.D. Department & 40 & 24 & 40 & 39 & 42 & 45 & 41 & 40 \\
\hline MA Department & 11 & 14 & 16 & 16 & 14 & 11 & 16 & 17 \\
\hline Undergrad Department & 25 & 29 & 29 & 30 & 31 & 31 & 32 & 33 \\
\hline Two Year College & 2 & 3 & 2 & 2 & 2 & 2 & 2 & 2 \\
\hline Non-Academic & 15 & 15 & 13 & 13 & 11 & 10 & 10 & 8 \\
\hline Post-Doc & 6 & 6 & - & - & - & - & - & - \\
\hline Don't Knowa & 0 & 9 & - & - & - & - & - & \\
\hline
\end{tabular}

The number is 0 due to the rounding off of percentages.

\section{TABLE 4}

Placement Experience of 1998 Political Science Doctoral Students, by Gender, Ethnicity, and Citizenship (\%)

\begin{tabular}{|c|c|c|c|c|c|c|c|c|}
\hline & \multicolumn{6}{|c|}{ U.S. Citizens $N=820$} & \multirow{2}{*}{\multicolumn{2}{|c|}{$\begin{array}{c}\text { Non-US Citizens } \\
N=135\end{array}$}} \\
\hline & \multicolumn{2}{|c|}{ All U.S. Citizens } & \multicolumn{4}{|c|}{ Minority Candidates } & & \\
\hline & $\begin{array}{c}\text { Men } \\
N=553\end{array}$ & $\begin{array}{l}\text { Women } \\
N=267\end{array}$ & $\begin{array}{c}\text { African } \\
\text { American } \\
N=47\end{array}$ & $\begin{array}{l}\text { Latino } \\
N=23\end{array}$ & $\begin{array}{c}\text { Asian } \\
\text { American } \\
\mathrm{N}=9\end{array}$ & $\begin{array}{c}\text { Native } \\
\text { American } \\
\mathrm{N}=8\end{array}$ & $\begin{array}{c}\text { Men } \\
N=100\end{array}$ & $\begin{array}{l}\text { Women } \\
N=35\end{array}$ \\
\hline Placement Class & 67 & 33 & 6 & 3 & 1 & 0.8 & 74 & 26 \\
\hline Repeating & 50 & 37 & 26 & 43 & 22 & 37 & 32 & 20 \\
\hline $\mathrm{PhD}$ & 63 & 60 & 38 & 57 & 78 & 75 & 67 & 54 \\
\hline ABD & 37 & 40 & 62 & 43 & 22 & 25 & 33 & 46 \\
\hline Placed & 71 & 73 & 79 & 70 & 67 & 63 & 73 & 83 \\
\hline Place w/PhD & 52 & 51 & 36 & 43 & 56 & 38 & 56 & 51 \\
\hline -Perm. Position & 29 & 29 & 21 & 22 & 22 & 40 & 14 & 14 \\
\hline -Temp. Position & 21 & 18 & 13 & 22 & 22 & 27 & 15 & 17 \\
\hline -Outside U.S. & 2 & 4 & 2 & 0 & 11 & 0 & 27 & 20 \\
\hline Place w/ABD & 19 & 21 & 43 & 26 & 11 & 20 & 17 & 31 \\
\hline -Perm. Position & 7 & 9 & 23 & 9 & 11 & 15 & 5 & 20 \\
\hline -Temp. Position & 12 & 10 & 19 & 17 & 0 & 0 & 9 & 9 \\
\hline -Outside U.S. & 1 & 1 & 0 & 0 & 0 & 0 & 3 & 3 \\
\hline Not Placed & 26 & 22 & 17 & 22 & 44 & 37 & 20 & 17 \\
\hline Unknown & 2 & 3 & 2 & 4 & 0 & 0 & 5 & 0 \\
\hline
\end{tabular}




\begin{tabular}{|c|c|c|c|c|c|c|c|}
\hline & 1998 & 1997 & 1996 & 1995 & 1994 & 1992 & 1990 \\
\hline Overall \% of Candidates Who Were Placed & 71 & 70 & 65 & 72 & 69 & 74 & 72 \\
\hline$\%$ of those placed with a Ph.D & 84 & 80 & 77 & 85 & 82 & 79 & 78 \\
\hline$\%$ of those placed with a $A B D$ & 53 & 53 & 49 & 56 & 50 & 66 & 63 \\
\hline$\%$ of those placed who are Men & 72 & 68 & 62 & 72 & 67 & 73 & 73 \\
\hline$\%$ of those placed who are Women & 74 & 73 & 70 & 71 & 74 & 75 & 70 \\
\hline$\%$ of Candidates Placed in Temporary Positions & 31 & 33 & 29 & 34 & 29 & 32 & 21 \\
\hline Men & 31 & 33 & 30 & 36 & 29 & 34 & NA \\
\hline Women & 28 & 32 & 26 & 31 & 29 & 38 & NA \\
\hline
\end{tabular}

\section{Women in the 1998 Placement Class}

Overall, women seem to be doing marginally better than they were a decade ago. As Table 2 shows, the percentage of women in the placement class has gradually increased over the past 10 years to $32 \%$. This proportion has fluctuated over time, but has tended upwards.

Table 4 presents information about the placement class by gender, ethnicity, and citizenship. Though there are still twice as many men as women on the political science job market, gender does not seem to affect placement, at least among U.S. citizens. Seventy-one percent of the U.S. males found jobs, while $73 \%$ of U.S. females did. Encouragingly, three-fourths (74\%) of all the women in the 1998 placement class found employment (see Table 5) and fewer women found it necessary to accept temporary positions in 1998 than in any year since 1988.

\section{Minorities in the 1998 Placement Class}

In $1998,11 \%$ of U.S. citizens in the placement class were minorities: 6\% were African American, 3\% were Latina/o, $1 \%$ were Asian American, and $0.8 \%$ were Native American (see Table 1). By percentages, African Americans had the most success among members of the 1998 placement class; $79 \%$ found jobs. Latina/os found jobs at rates comparable to whites. Asians had the lowest placement rate among identified groups (see Table 4). Three percent of the placement class were identified only as "other."
The other category is not included in the minority figures.

\section{Conclusions}

Though $70 \%$ or so of political science job seekers consistently find some kind of employment each year, two-fifths of them find only temporary employment and about $30 \%$ do not find work at all. Over the last decade, an average of $81 \%$ of those placed each year have had Ph.D.s, while just over half of the ABDs on the market find employment in any given year. Many job searches are taking two or more placement "seasons," and many more candidates are opting for nonacademic jobs. What can we do to increase the proportion of students placed in permanent positions?

- We need to ensure that students understand the market and realize that going out too early and without the Ph.D. in hand is not generally a good tactic and leads to multiple years of possibly frustrating, and expensive, job searching.

- Students should be encouraged to attend conferences and workshops and to publish. More and more students on the job market have publications, making the job market increasingly competitive.

- Students need to start career planning early and must remain open to a variety of opportunities. Diversification in fields of study and ranges of skills can make students more appealing candidates for an academic job and could also help a student land a nonfaculty position.
Additional information on placement is available via APSANet $<$ www.apsanet.org/ jobsplc/placement>

Tables on web site include:

Placement Success (1988-98)

Placement Success by Gender

Placement Success of Minorities

Placement Success by Field of Study (1990-98)

Placement of Candidates in Different Fields of Study by Gender, Citizenship, and Ethnicity

Distribution of Jobs According to Candidate's Field of Specialization (1990-98)

Placement of Candidates in Academic and Non-Academic Jobs by Gender, Citizenship, and Ethnicity

Placement by Type of Hiring Institution (1990-98)

Placement Experience of 1998 doctoral Students by their Status of Repeating the Job Search

Plans of 1998 Doctoral Candidates Not Placed in U.S. Institutions

Ph.D. Departments' Evaluation of Placement

Non-U.S. Citizens in 1998

Placement Class by Field

Country of Origin of all Non-U.S. Placement Candidates

Number of First Listings in PSN 


\section{P ROCE E I N G S \\ Political Research Online}

http://pro.harvard.edu http://pro.harvard.edu http://pro.harvard.edu http://pro.harvard.edu http://pro.harvard.edu

Papers for APSA's 96th Annual Meeting are now available on PROceedings, the online searchable collection of APSA Annual Meeting Papers and abstracts.

PROceedings features numerous subfields of political science, making it a valuable resource for research and teaching. Find papers using keyword searches or by browsing the APSA Annual Meeting Program.
Submission is simple. Authors receive "express passes" that minimize the effort required to submit papers.

If you have not submitted your paper to PROceedings, you still have time. Submission closes on September 3, the final day of the Annual Meeting.

Papers from the 2000 meeting are now available at http://pro.harvard.edu will remain online through August, 2001.

PROceedings aims to disseminate political science research more broadly and directly, to continue the scholarly exchange of the Annual Meetings beyond their setting, to encourage the instructional use of research and to facilitate individual and library access to Annual Meeting papers.
PROceedings is a collaborative effort of the American Poltical Science Association, the Harvard University Library, and The College of New Jersey, under the direction of William J. Ball. PROceedings was introduced at the 1997 Annual Meeting and is supported by a grant from the Andrew W. Mellon Foundation. 